\title{
Evaluation of the chemical composition of aquatic environments with leaf litter decomposition of Eucalyptus urophylla S.T. Blake (Myrtaceae) and their toxicity in Allium cepa L. (Amaryllidaceae)
}

Ritielly Maria Guimarães Guerino ( $\sim$ bioguerino@gmail.com )

State University of Goias: Universidade Estadual de Goias https://orcid.org/0000-0003-0662-6154

Junilson Augusto Silva

State University of Goias

Débora de Jesus Pires

State University of Goias: Universidade Estadual de Goias

Rafael Aparecido Carvalho Souza

Federal University of Uberlandia: Universidade Federal de Uberlandia

Raquel Maria Ferreira Sousa

Federal University of Uberlandia: Universidade Federal de Uberlandia

Alberto Oliveira

Federal University of Uberlandia: Universidade Federal de Uberlandia

Isa Lucia Morais

State University of Goias: Universidade Estadual de Goias

\section{Research Article}

Keywords: Allelochemicals, allelopathic eucalyptus compounds, chemical composition, cytotoxicity, toxicity, wetlands

Posted Date: November 19th, 2021

DOl: https://doi.org/10.21203/rs.3.rs-982957/v1

License: (9) (1) This work is licensed under a Creative Commons Attribution 4.0 International License. Read Full License 


\section{Abstract}

Allelochemicals from eucalyptus released into the environment, mainly by leaves, can have a toxic effect on local biota, including in aquatic environments. Therefore, the present study evaluates the toxic activity of the water containing leaves of Eucalyptus urophylla S.T. Blake (Myrtaceae) in decomposition using Allium cepa L. (Amaryllidaceae) as a test organism. The toxicity and the cytotoxicity evaluation were performed using onion bulbs (A. cepa). The toxicity was assessed by inhibiting root growth. The cytotoxicity was evaluated by using a comparison of the mitotic index (MI) and the negative control. The extraction of eucalyptus metabolites from water of the decomposition tests and creek water was performed by solid-phase microextraction (SPME). The chemical characterization was done by gas chromatography coupled to mass spectrometry (GC-MS). There was inhibition of the root growth of $A$. cepa, indicating toxicity of the compounds released in the water during the decomposition. The cytotoxicity tests did not indicate a toxic effect. However, there were identified some mutations, cell death, and morphological changes in the roots. 26 compounds were identified on samples of water acquired from decomposition tests.Fenchone, 2-ethyl-1-hexanol, cis-dihydrocarvone, and transdihydrocarvone were identified in all samples. The results highlight the importance of studies and monitoring of aquatic environments near eucalyptus.

\section{Introduction}

The expansion of eucalyptus culture has attracted attention because it is associated with different negative impacts on the environment. Among the environmental concerns is the planting of Eucalyptus species close to rivers, dams, etc. This concern is due to the presence of allelopathic compounds, mainly in the leaves, which impair the development of other plants and hinder the process of microbiological decomposition of the residues (Silva \&Costa 2004).

Allelochemicals are bioactive secondary metabolites produced by plants resulting from chemical interactions between plants and other organisms that cause interference in plant growth (Latif et al. 2017). These compounds have very specific ecological and physiological functions involved in biotic and abiotic interactions in ecosystems. The main functions are related to protection against herbivory, the attraction of pollinators, and water and temperature control (Simões et al. 2010). Among the most common allelochemicals are terpenes, alkaloids, phenolic compounds, steroids, long-chain fatty acids, and unsaturated lactones (Rice 1984). Specifically, for the Eucalyptus genus, there are compounds such as 1,8-cineol (eucalyptol, which is the major compound in most species), piperitone, felandrene, and volatile aldehydes, including aliphatics and aromatics, which have toxic effects (Araújo et al. 2010) and are inhibitory microbial (Canhoto \&Graça 1999).

The eucalyptus leaves dispersed in the burlap during the rainy season are carried to rivers and ponds through leaching, and, in contact with water, they release chemical constituents. The permanence of these in the aqueous environment represents a potential risk to aquatic organisms (Abelho \&Graça 1996). These effects can be verified through toxicity tests that are used to evaluate the potentially toxic effect of chemicals compounds present in the contaminated water and aim to collect information to record the elements and chemical compounds involved, and, inherent in the contaminated water and thus used for comparison with the standard values allowed (Brota 2012). 
Among the toxicity tests are those in the ecotoxicology area, which covers the study of the behavior and transformations of chemical agents in the environment, as well as their effects and responses on living organisms (Júnior et al. 2013). In this vein, studies have been conducted in aquatic ecosystems, through tests with organisms that allow the identification of problems and the monitoring of these ecosystems (Cesar et al. 1997). Thus, a toxicity test was performed with Allium cepa L. (onion), which is considered effective when used to assess the quality of waters. This test consists of studying macroscopic parameters, root growth inhibition values, and cytological parameters such as cell aberrations in metaphases or anaphases and mitotic cells (Fiskesjö 1988). The use of $A$. cepa becomes interesting due to its high sensitivity, low cost, speed, and ease of manipulation and allows it to determine the reduction of the mitotic index and the formation of chromosomal aberrations (Leme \&Marin-Morales 2009). Furthermore, the test has been internationally validated as a bioindicator of environmental contamination (Evseeva et al. 2003) and is commonly used to assess the genotoxic and cytotoxic potential of substances (Barbério et al. 2009).

In this context, this research aimed to evaluate the toxic activity of decomposition water of leaves of Eucalyptus urophylla S.T. Blake using A. cepa as a test organism and to identify the compounds presents on aqueous extract by gas chromatography coupled to mass spectrometry (GC-MS).

\section{Material And Methods}

\subsection{Leaves of E. urophylla and creek water}

Leaves of E. urophylla and creek water were collected by a litter of eucalyptus at $18^{\circ} 42^{\prime} 09.5^{\prime \prime} S$ and $49^{\circ} 10^{\prime} 01.1$ "W contiguous to the riparian vegetation of the Córrego da Areia. This watercourse belongs to the hydrographic basin of the Paranaíba River and is located in the Canápolis, Minas Gerais.

The identification of $E$. urophylla was done with the aid of a botanical identification key, by comparison with images present in Flores et al. (2016) and by species confirmation through a photographic record by a specialist.

\subsection{Simulated test of the leaf's decomposition in water}

The leaves of E. eucaliptus $(6.0 \mathrm{~g})$ and distilled water $(1.0 \mathrm{~L})$ were placed in glass containers, closed, and stored in an environment with low lighting. The experiments were organized into 4 groups based on the decomposition time: 5, 10, 15, and 30 days (adapted from Zoratto (2007)). After each decomposition period, the decomposition was filtered to perform biological and chemical analysis.

\subsection{Toxicity and cytotoxicity analysis}

The bioassay followed the protocol of Fiskesjo (1988). Fifteen bulbs of Allium cepa of similar sizes (about 3,5 $\mathrm{cm}$ in diameter), originating from organic culture and acquired in the Itumbiara, Goiás, were used. The primordial ring (where the roots emerge) was carefully cleaned and the golden bark of the bulbs was removed.

The decomposition water of leaves was used in concentrations of $25 \%, 50 \%$, and $100 \%$ in distillate water. Three bulbs were used for each concentration and they were in contact with the samples for seven days. Three 
bulbs were exposed to distilled water as a negative control, and three bulbs as a positive control were prepared using copper sulfate $\left(0.06 \mathrm{~g} \mathrm{~L}^{-1}\right)$.

After seven days the toxicity was assessed by the root growth index obtained from the average growth of the three largest roots of each bulb. The influence of concentrations and days of decomposition on root growth was performed with ANOVA Factorial test using the R program (R Core Team 2018).

The cytotoxicity through bulb roots was evaluated in a microscope (Leica Zeiss Modelo DMC2900) with slides prepared with cut roots and placed in an ethanol/acetic (3:1) acid fixing solution, counting 5,000 cells for each treatment and controls. Changes in Morphological cell indicating cell death and the frequency of mitotic index (Ml, according to the equation (Francisco 2011): $\mathrm{Ml}=$ (number of cells in division / total number of cells observed) $x$ 100) were analyzed. The values obtained were compared with those obtained in the negative control, using the chi-square test.

\subsection{Chemical characterization by gas chromatography coupled to mass spectrometry (GC-MS)}

The compounds presented in the decomposed water, extract from eucalyptus leaves, and in the water from the Córrego da Areia were extracted by the SPME method and analyzed in sequence by GC-MS.

Polydimethylsiloxane/divinylbenzene (PDMS/DVB) fiber with $d_{f} 65 \mu m$ (Sigma-Aldrich) was used in SPME. For extraction, $5 \mathrm{~mL}$ of sample was placed in headspace flasks with $20 \mathrm{~mL}$ capacity and sealed. It was heated at $60^{\circ} \mathrm{C}$ under stirring for $10 \mathrm{~min}$. Next, the fiber was added to the GC-MS of Shimadzu (QP2010 model) for analysis of the chemical composition. The conditions used were: capillary column type DB-5 (J\&W, $30 \mathrm{~m} \times 0.25 \mathrm{~mm} \times 0.25 \mathrm{~m})$, helium as a carrier gas with a constant flow of $1.0 \mathrm{~mL} \mathrm{~min}-1$; injector temperature of $200^{\circ} \mathrm{C}$; detector temperature of $230^{\circ} \mathrm{C}$; interface temperature of $275^{\circ} \mathrm{C}$, splitless injection mode; $10 \mathrm{~min}$ of desorption time of SPME; the temperature of the oven was $40^{\circ} \mathrm{C}$ for $5 \mathrm{~min}$, after this the oven temperature increase to $125^{\circ} \mathrm{C}$ at $2.5^{\circ} \mathrm{C} \mathrm{min}{ }^{-1}$, and increase to $245^{\circ} \mathrm{C}$ at $10^{\circ} \mathrm{C} \mathrm{min}-1$, maintained for $15 \mathrm{~min}$; the ionizing potential of $70 \mathrm{eV}$; the range of $\mathrm{m} / \mathrm{z} 40-650$. The identification of the compounds by this technique was based on the similarity index (SI) obtained by the software (LabSolution-GC-MS Solution) was also used by comparison with spectra present in the Nist27, Nist147, Wiley7, Wiley229, and Shim2205 libraries.

\section{Results And Discussion 3.1. Toxicity test}

The growth of the roots can occur by the production of new cells, which happens in the meristematic zone, and by the extension of the already formed cells, which occurs both in the meristemic zone and in the root elongation zone (Cutler et al. 2011). However, root growth can be compromised in the presence of toxic substances (Fiskesjö 1988). Thus, was evaluated the toxicity of decomposition water of leaves of Eucalyptus urophylla S.T. Blake using A. cepa. The results of the toxicity analysis through root growth inhibition are summarized in Table 1, which is observed as the mean root growth value of $A$. cepa exposed to different concentrations of the decomposition water of leaves in different periods of days. 
Table 1

Mean root growth values in centimeters $(\mathrm{cm})$, treatments, and controls for the three largest roots of each Allium cepa bulb.

\begin{tabular}{|lllll|}
\hline Sample concentration (\%) & \multicolumn{4}{l}{ Mean root growth $(\mathbf{c m})$} \\
\cline { 2 - 5 } & $\mathbf{5}$ days & $\mathbf{1 0}$ days & $\mathbf{1 5}$ days & $\mathbf{3 0}$ days \\
\hline 100 & $1.49 \pm 0.41$ & $1.51 \pm 0.19$ & $3.32 \pm 0.18$ & $2.43 \pm 0.15$ \\
\hline 50 & $2.29 \pm 0.25$ & $2.63 \pm 0.17$ & $3.34 \pm 0.30$ & $5.18 \pm 0.39$ \\
\hline 25 & $3.71 \pm 0.29$ & $3.1 \pm 0.19$ & $3.94 \pm 0.42$ & $6.17 \pm 0.08$ \\
\hline Control $(+) *$ & $0.12 \pm 0.06$ & $0.12 \pm 0.06$ & $0.12 \pm 0.06$ & $0.12 \pm 0.06$ \\
\hline Control $(-) * *$ & $5.79 \pm 0.13$ & $5.79 \pm 0.13$ & $5.79 \pm 0.13$ & $5.79 \pm 0.13$ \\
\hline Note: *control (+): copper sulfate, **control (-): distilled water & \\
\hline
\end{tabular}

The influence of the sample concentrations and the decomposition time of the eucalyptus leaves in water are summarized in Figure 1. From this result, it was possible to observe that the growth of the root of the $A$. cepa bulbs, about the control group, was influenced by both the concentration and the decomposition time of the leaves in water (ANOVA Factorial; $F=7.608$; $P<0.001$ ). The samples with $100 \%$ leaf decomposition water concentration and periods of the 5 and 10 days of decomposition were the most inhibited the root growth.

The sample with $25 \%$ concentration and 30 days of decomposition inhibited root growth the least when compared to the control group.

The inhibition of root growth is indicative of the presence of compounds with toxic effects. Ribeiro (1997) showed the toxicity of industrial effluents through tests to inhibit $A$. cepa roots (Ribeiro 1997). Using the same test, Moreira et al. (2014) showed the toxic effect of the pesticide deltamethrin (Moreira et al. 2014). The inhibition growth of the $A$. cepa root in leaf decomposition water may be related to the release of chemical constituents from leaves in decomposition (Abelho \&Graça 1996). Thus, the inhibition of $A$. cepa root growth may have been due to the presence of terpenes. Monoterpenes can inhibit germination and root growth in several species since these compounds can cause the reduction of mitotic activity and lipid globules formation in plants (Steven \&Gayland 1993).

In vitro ecotoxicological tests using crustaceans of the species Daphnia laevis and Daphnia similis as bioindicators have already indicated the ecotoxicological potential of the volatile oil of the litter of $E$. urograndis (hybrid species), in addition to deleterious effects on aquatic biota (Araújo et al. 2010). Also, ecotoxicological evaluations showed the toxic effect of the natural compounds produced by $E$. grandis and $E$. urophylla using leaf decomposition water with essential oils and extracts of different polarities of these two species, even in small concentrations. Both species warn of possible harmful impacts on aquatic ecosystems located around areas with eucalyptus cultivation (Zoratto 2007).

\subsection{Cytotoxicity test}

The cytotoxicity test was assessed using the mitotic index (MI), which is determined through the rate of cell division (Francisco 2011). The MI values were compared with those obtained in the negative control (Table 2) 
and the results of the chi-square test were not significant $\left(X^{2}=1.348 ; D F=9 ; p<0.998\right)$. A low Ml, compared to the control group, indicates that there were chemical changes capable of interfering with the growth and development of the organism, while a higher MI than that observed in the control group indicates an increased cell division, which is harmful because it causes disorderly multiplication and tumor formation (Leme \&MarinMorales 2009). Thus, it can be inferred that there was no effect of days and concentration on the MI. However, it is possible to observe changes in the cell cycle of the roots exposed to different concentrations on the slides, besides some aberrations and signs of cell death (Fig. 2, 3 and 4). The roots of the positive control did not show sufficient growth for making slides, so it was not possible to calculate the MI of this group.

Table 2

Miotic index (\%) of $A$. cepa roots with different concentrations (\%) of the decomposition water of eucalyptus leaves in different periods (days).

\begin{tabular}{|lllll|}
\hline Sample concentration (\%) & \multicolumn{4}{l|}{ Mitotic index - MI (\%) } \\
\cline { 2 - 5 } & $\mathbf{5}$ days & $\mathbf{1 0}$ days & $\mathbf{1 5}$ days & $\mathbf{3 0}$ days \\
\hline 100 & 20.34 & 21.98 & 21.04 & 21.06 \\
\hline 50 & 25.10 & 23.38 & 23.96 & 23.42 \\
\hline 25 & 23.12 & 21.90 & 28.98 & 21.04 \\
\hline Control $(-) *$ & 34.98 & 34.98 & 34.98 & 34.98 \\
\hline Note: ${ }^{*}$ Control (-): distilled water. & & & \\
\hline
\end{tabular}

Slides with histological sections from the negative control showed a better visualization of the cells, as well as their nuclei and cell division stages. The nucleus of the control cells is well condensed, which contributes to better staining. In the other slides, the roots exposed to the treatments with the water of decomposition of the leaves of E. urophylla, the nucleus is compartmentalized and little condensed, which prevents the fixation of the dye and, consequently, the visualization. In some cases, as in (Fig. 2c), the presence of many vacuoles means cell death, and it is not possible to visualize the cell's genetic material. Some studies using the same bioindicator, but subjected to tests with different substances, showed similar mutations during the division process (Leme \&Marin-Morales 2009, Mendes 2008, Paula et al. 2015).

It is worth mentioning that the roots of the present study also showed different morphological characteristics from the control group, especially those exposed to $100 \%$ concentrations in the periods of 15 and 30 days. The roots of this treatment, even showing root growth, had a soft texture and thin thickness, which made it difficult to make good quality slides.

\subsection{Chemical composition}

The chemical composition of volatile compounds presents in the leaf decomposition water (in different periods) and the aqueous extract of the leaves of the litter of $E$. urophylla were extracted by the SPME method and identified by GC-MS. (Table 3 and Fig. 5) show all compounds identified and lists according to their retention time. A total of 26 compounds were identified in the aqueous extract and decomposition water of leaves, where was identified at least $87 \%$ of compounds present in the samples. 
Table 3

Chemical composition present in the leaf decomposition water at different periods (days) and in the aqueous extract of the leaves of the litter of E. urophylla.

\begin{tabular}{|c|c|c|c|c|c|c|}
\hline & & 5 days & 10 days & 15 days & 30 days & fresh leaves \\
\hline $\begin{array}{l}\text { RT } \\
(\min )\end{array}$ & Compounds & $\operatorname{TIC}(\%)$ & $\operatorname{TIC}(\%)$ & $\operatorname{TIC}(\%)$ & $\operatorname{TIC}(\%)$ & $\operatorname{TIC}(\%)$ \\
\hline 12.53 & a-pinene (1) & - & - & $4.6 \pm 0.71^{a}$ & - & $11.10 \pm 0.46^{\mathrm{e}}$ \\
\hline 18.01 & cymene (o or $p)(2)$ & - & - & - & - & $2.81 \pm 0.69^{e}$ \\
\hline 18.55 & eucalyptol (3) & - & - & - & - & $60.97 \pm 0.63^{e}$ \\
\hline 18.59 & 2-ethyl-1-hexanol (4) & $10.6 \pm 0.89^{a}$ & $12.59 \pm 0.61^{d}$ & $8.59 \pm 0.43^{d}$ & $5.01 \pm 1.20^{c}$ & - \\
\hline 20.97 & cis-linalyl oxide (5) & $2.32 \pm 1.35^{\mathrm{a}}$ & $3.61 \pm 1.00^{\mathrm{a}}$ & - & $3.43 \pm 1.09^{a}$ & - \\
\hline 21.73 & fenchone (6) & $8.73 \pm 1.31^{a}$ & $8.04 \pm 0.75^{\mathrm{e}}$ & $7.26 \pm 1.36^{\mathrm{e}}$ & $12.3 \pm 0.21^{\mathrm{e}}$ & - \\
\hline 23.02 & $\begin{array}{l}\text { 2,2,6-trimethyl-3- } \\
\text { keto-6- } \\
\text { vinyltetrahydropyran } \\
\text { (7) }\end{array}$ & - & - & - & $4.43 \pm 0.21^{c}$ & - \\
\hline 23.33 & fenchol (8) & - & - & - & - & $1.01 \pm 0.20^{c}$ \\
\hline 24.06 & a-campholenal (9) & - & - & - & - & $0.89 \pm 0.06^{c}$ \\
\hline 24.76 & $\begin{array}{l}\text { trans-pinocarveol } \\
(10)\end{array}$ & - & - & - & - & $1.68 \pm 0.24^{\mathrm{e}}$ \\
\hline 25.01 & camphor (11) & $9.48 \pm 0.50^{\mathrm{a}}$ & $7.89 \pm 0.10^{\mathrm{a}}$ & - & $20.67 \pm 0.32^{\mathrm{a}}$ & - \\
\hline 25.99 & $\begin{array}{l}\text { trans- } \\
\text { pinocamphone (12) }\end{array}$ & $6.20 \pm 0.61^{\mathrm{e}}$ & $5.32 \pm 0.02^{\mathrm{e}}$ & $8.70 \pm 1.41^{\mathrm{e}}$ & - & - \\
\hline 26.13 & pinocarvone (13) & $8.01 \pm 0.26^{\mathrm{e}}$ & $1.44 \pm 0.59^{e}$ & $1.25 \pm 0.38^{\mathrm{e}}$ & - & $1.26 \pm 0.23^{\mathrm{e}}$ \\
\hline 26.39 & isoborneol (14) & - & - & - & - & $1.37 \pm 0.20^{c}$ \\
\hline 26.77 & $\begin{array}{l}\text { cis-pinocamphone } \\
\text { (15) }\end{array}$ & $3.36 \pm 0.08^{d}$ & $8.68 \pm 0.32^{d}$ & $3.84 \pm 1.05^{\mathrm{a}}$ & - & - \\
\hline 27.77 & trans-isocarveol (16) & $10.6 \pm 0.48^{d}$ & $11.47 \pm 0.61^{\mathrm{e}}$ & $11.79 \pm 0.26^{d}$ & - & - \\
\hline 27.91 & a-terpineol (17) & - & - & - & - & $2.38 \pm 0.55^{c}$ \\
\hline 28.20 & $\begin{array}{l}\text { cis-dihydrocarvone } \\
\text { (18) }\end{array}$ & $8.67 \pm 0.24^{e}$ & $10.02 \pm 0.09^{e}$ & $16.56 \pm 0.11^{\mathrm{e}}$ & $24.26 \pm 0.12^{\mathrm{e}}$ & - \\
\hline 28.59 & $\begin{array}{l}\text { trans- } \\
\text { dihydrocarvone (19) }\end{array}$ & $7.14 \pm 0.14^{e}$ & $8.77 \pm 0.04^{d}$ & $18.91 \pm 0.55^{d}$ & $21.77 \pm 0.29^{e}$ & - \\
\hline
\end{tabular}

Note: RT: retention time; Identification method by similarity index with mass spectral database: a=Nist08s, b=Nist08, c= Wiley139, d=Wiley229, e=Shim225. 


\begin{tabular}{|c|c|c|c|c|c|c|}
\hline & & 5 days & 10 days & 15 days & 30 days & fresh leaves \\
\hline 29.29 & $\begin{array}{l}\text { iso-dihydrocarveol } \\
(20)\end{array}$ & $3.96 \pm 0.29^{c}$ & $5.52 \pm 0.14^{d}$ & $6.43 \pm 0.13^{d}$ & - & - \\
\hline 30.02 & nerol (21) & $5.94 \pm 0.16^{d}$ & $3.71 \pm 0.18^{d}$ & - & - & - \\
\hline 36.71 & $\begin{array}{l}\text { a-terpinyl acetate } \\
(22)\end{array}$ & - & - & - & - & $10.55 \pm 0.27^{d}$ \\
\hline 39.95 & $\begin{array}{l}\text { trans-caryophyllene } \\
\text { (23) }\end{array}$ & - & - & - & - & $1.47 \pm 0.13^{\mathrm{C}}$ \\
\hline 43.84 & aromadendrene (24) & - & $0.67 \pm 0.09^{b}$ & $1.06 \pm 0.64^{c}$ & $2.45 \pm 0.13^{d}$ & $1.85 \pm 1.00^{\mathrm{b}}$ \\
\hline 44.16 & $\begin{array}{l}\text { caryophyllene oxide } \\
(25)\end{array}$ & $4.90 \pm 4.90^{\mathrm{e}}$ & - & - & - & - \\
\hline \multirow[t]{2}{*}{44.34} & $\begin{array}{l}\text { alloaromadendrene } \\
\text { (26) }\end{array}$ & - & $0.65 \pm 0.10^{a}$ & - & - & $1.11 \pm 0.10^{d}$ \\
\hline & Total identified (\%) & 89.94 & 87.69 & 88.97 & 94.31 & 98.43 \\
\hline
\end{tabular}

In the analysis of composition water from 10 days of decomposition had the largest number of compounds (14 compounds) while of the 30 days had the lowest (8 compounds). The chemical class (Table 4 ) of the volatile constituents shows that at least $55 \%$ of compounds are oxygenated monoterpenes, with this class representing approximately $80 \%$ of the constitution of the aqueous extract. Sesquiterpene hydrocarbons and oxygenated sesquiterpenes were found in small amounts, where the highest $(21.77 \%)$ was observed in the decomposition water of leaves of 5 days. These classes of compounds have different functions, such as insecticides and repellents (Reis et al. 2016), antifungal (Kh \&Abdelgaleil 2017), among others. Sesquiterpenes and monoterpenes were also the main compounds released by $E$. urophylla by leaves leaching and decomposition in the litter in a study that evaluates the compounds present in soil water (He et al. 2014).

Table 4

Chemical class distribution of compounds presents in the leaf decomposition water at different periods (days) and in the aqueous extract of the leaves of the litter of E. urophylla.

\begin{tabular}{|llllll|}
\hline Functional groups & $\mathbf{5}$ days (\%) & $\mathbf{1 0}$ days $(\%)$ & $\mathbf{1 5}$ days $(\%)$ & $\mathbf{3 0}$ days $(\%)$ & fresh leaves (\%) \\
\hline Monoterpenes & - & - & $4.6(1)$ & - & $13.91(2)$ \\
\hline Oxygenated monoterpenes & $55.25(10)$ & $70.17(10)$ & $74.62(8)$ & $78.99(3)$ & $80.09(8)$ \\
\hline Sesquiterpenes & - & - & $1.06(1)$ & - & $4.43(3)$ \\
\hline Oxygenated sesquiterpenes & $21.77(1)$ & $1.32(2)$ & - & $2.45(1)$ & - \\
\hline Oxirane & - & - & - & $4.43(1)$ & - \\
\hline Oxilane & $2.32(1)$ & $3.61(1)$ & - & $3.43(1)$ & - \\
\hline Aliphatic alcohol & $10.6(1)$ & $12.59(1)$ & $8.59(1)$ & $5.01(1)$ & - \\
\hline
\end{tabular}


The major compounds identified in the aqueous extract were eucalyptol (60.97\%), a-pinene (11.10\%), and aterpinyl acetate (10.55\%), all monoterpenes. These compounds are found in other Eucalyptus species in different proportions, as observed in other studies that evaluated the composition of essential oils (Baptista et al. 2015, Sebei et al. 2015). Hepp, Delanora, and Trevisan (2009) also identified secondary compounds during the decomposition of leaves of $E$. grandis in a stream for different periods, with some compounds similar to those found in this study, such as eucalyptol, fenchol, pinocarveol, pinocamfone, and terpineol.

The main compounds identified in the decomposition water of leaves of all days were all oxygenated monoterpenes. As observed in Table 3, a-pinene is presented only in the 15 days sample and the aqueous extract, the caryophyllene oxide is presented only in the 5 days sample and in aqueous extract and the 2,2,6trimethyl-3-keto-6-vinyltetrahydropyran is presented only in the 30 days sample. There is also a significant increase in the percentage of the cis-dihydrocarvone and trans-dihydrocarvone compounds over the days of decomposition of leaves, reaching 24.26 and $21.77 \%$, respectively, in the 30 days sample. The compounds aromadendrene and alloaromadendrene appeared only in samples of 10 and 15 days and 10 and 30 days, respectively.

According to the data presented, the 5 and 10 days periods showed similarities between the compounds, with nerol being a compound unique to these two periods. Nerol is a monoterpene found in many essential oils (Andrei \&Comune 2005, Peterson et al. 2006), that has biological potentials potentialities in several in vitro and in vivo test systems (Marques et al. 2013). This monoterpene is found in several medicinal plants, which are reported in the literature with antioxidant, antimicrobial and neuroprotective activities (Allahverdiyev et al. 2004, Escobar et al. 2010, Kennedy et al. 2003). Moreover, nerol is used as a fragrance in cosmetics and cleaning products (Santos et al. 1996).

The action is reported in the central nervous system (CNS), as an antidepressant, anxiolytic, antinociceptive and anticonvulsant, in addition to having antioxidant, anti-inflammatory, antimicrobial and anthelmintic activities (Almeida et al. 2014, Coelho 2017, Escobar et al. 2010, Lapczynski et al. 2008, Silva et al. 2014, Silva et al. 2012, Topal et al. 2008). Nerol can provide attractive, repellent and even toxic activity to insects and microorganisms, and provides an antispasmodic effect (Coelho 2017, Escobar et al. 2010, Silva et al. 2014). This chemical component has been shown to be toxic to Artemia salina and in the evaluation of hemolysis in mice at a concentration of $500 \mu \mathrm{g} / \mathrm{mL}$, nerol showed hemolytic and cytotoxic effect at the cellular level, causing membrane rupture (Coelho 2017).

\section{Conclusion}

This study shows that the compounds of E. urophylla released during the decomposition of the leaves in the water have an effect by the inhibition of Allium cepa root growth, mainly in the first 10 days.

The results of the cytotoxicity analysis did not indicate a significant toxic effect. However, it was possible to observe morphological changes, some mutations, and cell death in the histological sections of the A. cepa root.

The analysis by GC-MS identified 26 compounds released by the leaves of $E$. urophylla, most of which belong to the class of oxygenated monoterpenes. The compounds 2-ethyl-1-hexanol, fenchone, cis-dihydrocarvone, 
and trans-dihydrocarvone are important in the water decomposition of leaves and eucalyptol, a-pinene, and aterpinyl acetate in the aqueous extract.

Because of the results presented here, this research corroborates the risk of foreign materials for aquatic biota, especially in small environments with less water flow, such as in temporary puddles present in the litter, which are used, for example, for the reproduction of amphibians. Thus, it is important to monitor the aquatic environments close to the eucalyptus, as well as respect a minimum distance established by law and use natural barriers that prevent the eucalyptus leaves from being leached to the watercourse.

\section{Abbreviations}

GC-MS - gas chromatography coupled to mass spectrometry, DF - degrees of freedom, DVB - divinylbenzene, MI - mitotic index, PDMS - polydimethylsiloxane, RT - retention time, SPME - solid phase microextraction, SI similarity index.

\section{Declarations}

\section{ETHICS APPROVAL AND CONSENT TO PARTICIPATE}

Not applicable.

\section{CONSENT FOR PUBLICATION}

Not applicable.

\section{AVAILABILITY OF DATA AND MATERIALS}

All data generated or analysed during this study are included in this published article and its supplementary information file at https://docs.google.com/document/d/1UkNm1xKbzdzuPdl02wOllgstW5JHqHPWR3JEoPZmz7A/edit? usp=sharing

\section{COMPETING INTEREST}

The authors declare that they have no competing interests.

\section{FUNDING}

This research received no specific grant from any funding agency in the public, commercial, or not-for-profit sectors.

\section{AUTHORS' CONTRIBUTIONS}

Ritielly M. G. Guerino: Elaboration of all stages of construction of the article, elaboration of the project, bibliographic review, definition of the methodology, collection and treatment of data, discussion of the results and conclusion. Junilson A. P. Silva: Methodology. Débora de Jesus Pires: Methodology, Writing - original draft. Rafael A. C. Souza: Methodology, Writing - original draft. Raquel M. F. Sousa: Funding acquisition, Supervision, 
Conceptualization, Writing - review e editing. Alberto de Oliveira: Funding acquisition, Supervision, Conceptualization, Writing - review e editing. Isa Lucia de Morais: Supervision, elaboration of the project, bibliographic review, definition of the methodology, discussion of the results and conclusion, conceptualization, writing - review e editing.

\section{ACKNOWLEDGEMENTS}

This research was supported by grants from FAPEMIG (APQ-02342-18 and APQ-01612-18 awarded to R.M.F.S. and A.O., respectively). The authors thank Ricardo Reis Soares for GC-MS equipment, coordinators of the Improvement of Higher Education Personnel (CAPES, Cod. 001) for scholarships.

\section{References}

Abelho M, Graça MAS (1996): Effects of eucalyptus afforestation on leaf litter dynamics and macroinvertebrate community structure of streams in Central Portugal. Hydrobiologia 324, 195-204. DOI: https://doi.org/10.1007/BF00016391.

Allahverdiyev A, Duran N, Ozguven M, Koltas S (2004): Antiviral activity of the volatile oils of Melissa officinalis L. against Herpes simplex virus type-2. Phytomedicine. 11, 657-661. DOI: https://doi.org/10.1016/j.phymed.2003.07.014.

Almeida AACd, Carvalho RBFd, Sousa DPd, Souza GFd, Oliveira JdS, Freitas RMd (2014): Avaliação da toxicidade aguda do epóxilimoneno em camundongos adultos. Rev Cubana Plant Med 19, 160-171.

Andrei P, Comune APD (2005): Aromaterapia e suas aplicações. Cadernos 11, 57-68.

Araújo FOLd, Rietzler AC, Duarte LP, Silva GDdF, Carazza F, Vieira Filho SA (2010): Constituintes químicos e efeito ecotoxicológico do óleo volátil de folhas de Eucalyptus urograndis (Mirtaceae). Quim Nova 33, 15101513.

Baptista EB, Zimmermann-Franco DC, Lataliza AAB, Raposo NRB (2015): Chemical composition and antifungal activity of essential oil from Eucalyptus smithii against dermatophytes. Rev Soc Bras Med Trop 48, 746-752.

Barbério A, Barros L, Voltolini J, Mello M (2009): Evaluation of the cytotoxic and genotoxic potential of water from the River Paraíba do Sul, in Brazil, with the Allium cepa L. test Braz J Biol 69, 837-842. DOI: https://doi.org/10.1590/S1519-69842009000400010.

Brota GA 2012: Ensaios ecotoxicológicos em organismos-teste Daphnia similis e Vibrio fischeri na avaliação de efluentes sanitários aplicados na cultura de eucalipto (Eucaliptus urograndis). Master Thesis, Universidade Estadual de Campinas, Campinas, SP, 73 pp.

Canhoto C, Graça MA (1999): Leaf barriers to fungal colonization and shredders (Tipula lateralis) consumption of decomposing Eucalyptus globulus. Microb Ecol. 37, 163-172. DOI: https://doi.org/10.1007/s002489900140. 
Cesar A, Silva SLRD, Santos AR (1997): Testes de toxidade aquática no controle da poluição. Universidade Santa Cecília, Santos,SP, 37 pp.

Coelho ML 2017: Bioprospecção dos monoterpenos: dimetil-octanol, estragol e nerol com ênfase nas propriedades antioxidantes, esquistossomicidas e antimicrobianas. Doctoral Thesis, Universidade Federal Do Piauí, Teresina, 265 pp.

Cutler DF, Botha T, Stevenson DW, Moraes MGD, Santos RPD (2011): Anatomia Vegetal: Uma Abordagem Aplicada. Artmed, Porto Alegre

Escobar P, Leal Pinto S, Herrera L, Martínez J, Stashenko E (2010): Chemical composition and antiprotozoal activities of Colombian Lippia spp essential oils and their major components. Mem Inst Oswaldo Cruz 105, 184-190. DOI: https://doi.org/10.1590/S0074-02762010000200013.

Evseeva TI, Geras'kin SA, Shuktomova, II (2003): Genotoxicity and toxicity assay of water sampled from a radium production industry storage cell territory by means of Allium-test. J Environ Radioact. 68, 235-248. DOI: https://doi.org/10.1016/s0265-931x(03)00054-7.

Fiskesjö G (1988): The Allium test-an alternative in environmental studies: the relative toxicity of metal ions. Mutat Res. 197, 243-60. DOI: https://doi.org/10.1016/0027-5107(88)90096-6.

Flores T, Alcarde Alvares C, Souza V, Stape J (2016): Eucalyptus no Brasil: zoneamento climático e guia para identificação. IPEF, Piracicaba, 448 pp.

Francisco A 2011: Avaliação da toxicidade do cloreto de níquel utilizando Allium cepa como organismo teste. Trabalho de conclusão de curso Thesis, Universidade Estadual Paulista, Rio Claro, SP, 64 pp.

He H, Song Q, Wang Y, Yu S (2014): Phytotoxic effects of volatile organic compounds in soil water taken from a Eucalyptus urophylla plantation. Plant and Soil 377DOI: https://doi.org/10.1007/s11104-013-1989-1.

Hepp LU, Delanora R, Trevisan A (2009): Compostos secundários durante a decomposição foliar de espécies arbóreas em um riacho do sul do Brasil. Acta Bot Brasilica 23, 407-413. DOI: https://doi.org/10.1590/s010233062009000200012

Júnior HMdO, Sales PdTF, Oliveira DBd, Schimidt F, Santiago MF, Campos LC (2013): Characterization and genotoxicity evaluation of effluent from a pharmacy industry. Rev. Ambient. e Agua 8, 34-45. DOI: https://doi.org/10.4136/ambi-agua.1107

Kennedy DO, Wake G, Savelev S, Tildesley NT, Perry EK, Wesnes KA, Scholey AB (2003): Modulation of mood and cognitive performance following acute administration of single doses of Melissa officinalis (Lemon balm) with human CNS nicotinic and muscarinic receptor-binding properties. NPP 28, 1871-81. DOI: https://doi.org/10.1038/sj.npp.1300230.

Kh M, Abdelgaleil S (2017): Antifungal potential and biochemical effects of monoterpenes and phenylpropenes on plant. Plant Prot Sci 54, 9-16. DOI: https://doi.org/10.17221/9/2017-PPS. 
Lapczynski A, Foxenberg RJ, Bhatia SP, Letizia CS, Api AM (2008): Fragrance material review on nerol. Food Chem Toxicol. 46, S241-244. DOI: https://doi.org/10.1016/j.fct.2008.06.062.

Latif S, Chiapusio G, Weston LA (2017): Allelopathy and the role of allelochemicals in plant defence. In: Becard G (Editor), Advances in Botanical Research. Academic Press, pp. 19-54

Leme DM, Marin-Morales MA (2009): Allium cepa test in environmental monitoring: A review on its application. Mutat Res. 682, 71-81. DOI: https://doi.org/10.1016/j.mrrev.2009.06.002.

Marques T, Marques MLBGCB, Lima D, Siqueira H, Neto J, Branco MSBGC, Souza A, Sousa D, Freitas R (2013): Evaluation of the neuropharmacological properties of nerol in mice. World J Neurosci 03, 32-38. DOI: https://doi.org/10.4236/wjns.2013.31004.

Mendes MdS 2008: Elementos-traço em Allium cepa L. e Lactuca sativa L. Doctoral Thesis, Universidade Federal de Pelotas, Pelotas, RS, 160 pp.

Moreira TC, Moreira MDGC, Moreira VC, Leopoldo JR, Agostinho LDA (2014): Avaliação da toxicidade e da genotoxicidade da ivermectina e da deltametrina através de bioensaio com Allium cepa. Rev Cient Faminas 9 , 25-40.

Paula RPd, Bueno SSdS, Schmitt KFM, Tiago AV, Rossi AAB (2015): Sistema teste de Allium cepa como bioindicador de citotoxicidade e genotixicidade em Aristolochia elegans Mast. Enciclopédia Biosfera 11, 17491756.

Peterson A, Machmudah S, Roy B, Goto M, Sasaki M, Hirose T (2006): Extraction of essential oil from geranium (Pelargonium graveolens) with supercritical carbon dioxide. J Chem Technol Biotechnol 81, 167-172. DOI: https://doi.org/10.1002/jctb.1375.

Reis SL, Mantello AG, Macedo JM, Gelfuso EA, da Silva CP, Fachin AL, Cardoso AM, Beleboni RO (2016): Typical monoterpenes as insecticides and repellents against stored grain pests. Molecules 21, 258-258. DOI: https://doi.org/10.3390/molecules21030258.

Ribeiro IA 1997: Teste com raízes de cebola para avaliação de toxicidade de efluentes industriais. Master Thesis, Universidade de São Paulo, São Paulo, SP, 91 pp.

Rice E (1984): Allelopathy. Academic Press, New York

Santos FA, Rao VSN, Silveira ER (1996): Studies on the neuropharmacological effects of Psidium guyanensis and Psidium pohlianum essential oils. Phytother Res. 10, 655-658. DOI: https://doi.org/10.1002/(SICI)10991573(199612)10:8<655::AID-PTR933>3.0.CO;2-X.

Sebei K, Sakouhi F, Herchi W, Khouja ML, Boukhchina S (2015): Chemical composition and antibacterial activities of seven Eucalyptus species essential oils leaves. Biol Res 48, 7. DOI: https://doi.org/10.1186/07176287-48-7. 
Silva A, Júnior J, Silva M, Morais S (2014): Phytochemistry and biological activities of little lemon Zanthoxylum syncarpum Tull. Revista Brasileira de Higiene e Sanidade Animal 8, 37-53. DOI: https://doi.org/10.5935/1981-2965.20140003.

Silva AC, Costa ASVd (2004): Decomposição de partes vegetativas de eucalipto (Eucalyptus grandis) submetidas a extratos de diferentes solos. Revista Acadêmica Ciência Animal 2, 11-20. DOI: https://doi.org/10.7213/cienciaanimal.v2i2.15045.

Silva AP, Cerqueira GS, Nunes LC, de Freitas RM (2012): Effects of an aqueous extract of Orbignya phalerata Mart on locomotor activity and motor coordination in mice and as antioxidant in vitro. Die Pharmazie 67, 260263.

Simões CMO, Schenkel EP, Gosmann G, Mello JCPd, Mentz LA, Petrovick PR (2010): Óleos essenciais. In: UFRGS Ed (Editor), Farmacognosia: da planta ao medicamento. Editora da UFSC, Florianópolis

Steven FV, Gayland FS (1993): Volatile monoterpenes as potential parent ptructures for new herbicides. Weed Science 41, 114-119. DOI: https://doi.org/10.1017/s0043174500057672

Topal U, Sasaki M, Goto M, Otles S (2008): Chemical compositions and antioxidant properties of essential oils from nine species of Turkish plants obtained by supercritical carbon dioxide extraction and steam distillation. International journal of food sciences and nutrition 59, 619-634. DOI:

https://doi.org/10.1080/09637480701553816.

Zoratto AC 2007: Avaliação ecotoxicológica de compostos naturais produzidos por Eucalyptus grandis e Eucalyptus urophylla no Vale do Rio Doce, Minas Gerais. Master Thesis, Universidade de São Paulo, São Carlos, SP, $222 \mathrm{pp}$.

\section{Figures}




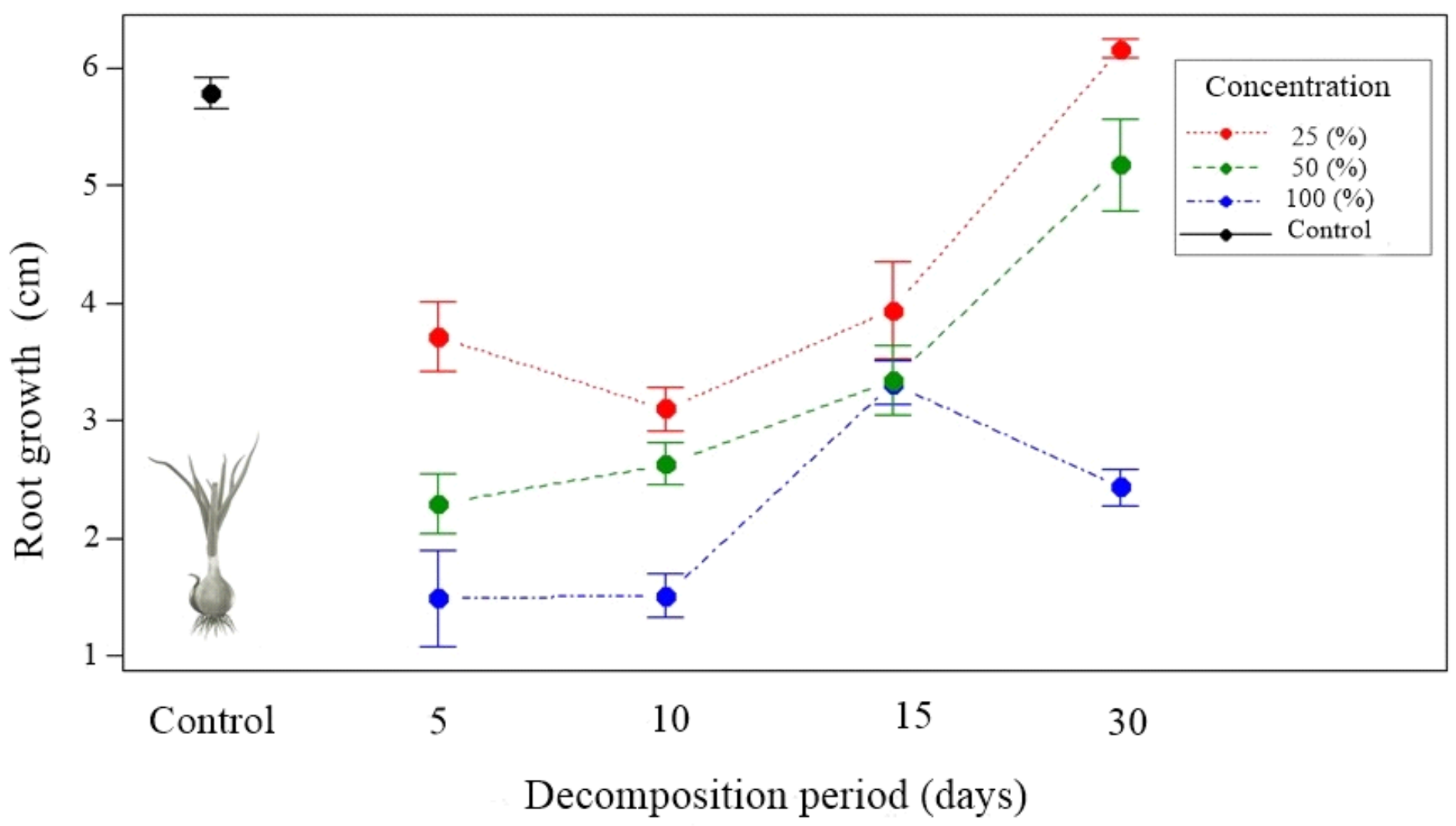

Figure 1

Influence of the concentration (\%) of leaf decomposition water and decomposition time (days) on root growth $(\mathrm{cm})$ of A. cepa (ANOVA Factorial test).

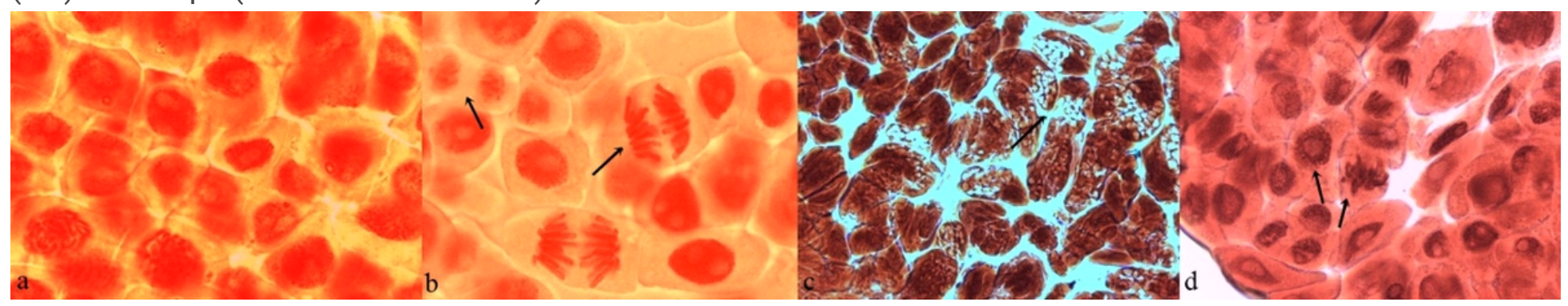

\section{Figure 2}

Meristematic cells of A. cepa root in the mitotic division. The arrows indicate: a) Cells from the negative control histological section; b) cells dividing the negative control into telophase and anaphase; $c$ ) root cells of treatment with decomposition water of leaves at 30 days at a concentration of $100 \%$ with signs of cell death; and d) root cells of treatment with decomposition water of leaves at 15 days at a concentration of $25 \%$ in irregular metaphase and anomalous interphase. 


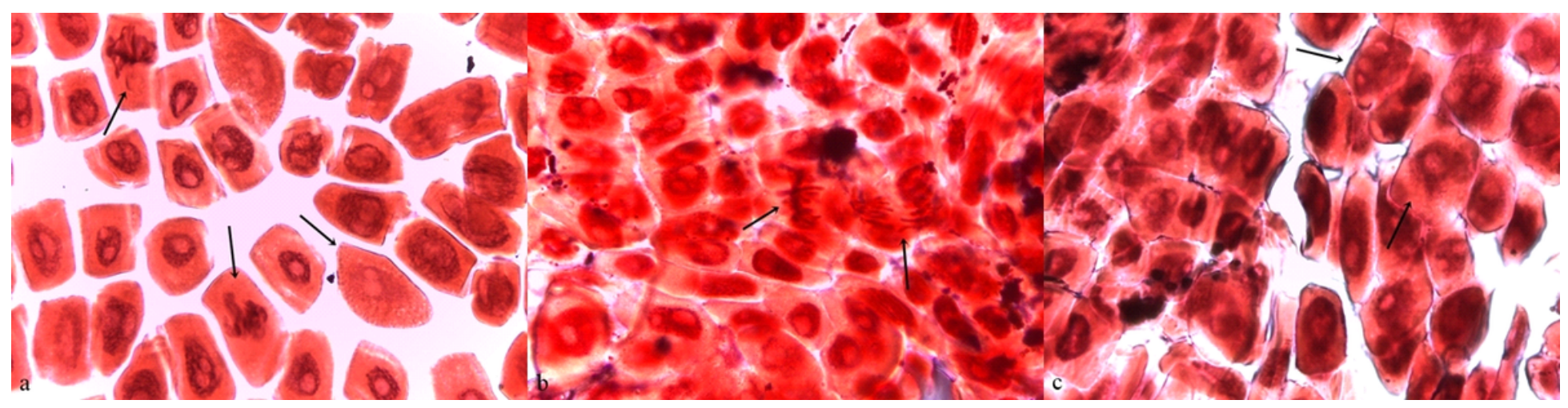

Figure 3

Meristematic cells of A. cepa root exposed to decomposition water of leaves of E. urophylla at 10 days. The arrows indicate a) Cells of the histological cut of the root of treatment with decomposition water of leaves at a concentration of $50 \%$ with the compartmented nucleus and anomalous metaphases; b) root cells of treatment with decomposition water of leaves at a concentration of $100 \%$ with abnormal metaphase and bridged telophase; and c) root cells of treatment with decomposition water of leaves at a concentration of $100 \%$ with signs of cell death.



Figure 4

Meristematic cells of the A. cepa root exposed to decomposition water of leaves of E. urophylla at 5 days. The arrows indicate a) Cells of the histological cut of the root of treatment with decomposition water of leaves at a concentration of $100 \%$ with abnormal prophase and compartmented nucleus; b) root cells of treatment with decomposition water of leaves at a concentration of $100 \%$ with abnormal prophase and compartmented nucleus; and c) root cells of treatment with decomposition water of leaves at a concentration of $25 \%$ with anomalous metaphase and signs of cell death. 
○

(1)<smiles>Cc1ccc(C(C)C)cc1</smiles>

(2)<smiles>CC12CCC(O1)C(C)(C)C2</smiles>

(3)<smiles>CC1=CCC(CC=O)C1(C)O</smiles><smiles>C=C1C[C@H]2C[C@@H]3[C@@H]1[C@@H]32</smiles><smiles>C[C@@H]1C(=O)[C@]2(C)CC[C@@H]1C2=O</smiles><smiles>C[C@@H]1C(=O)C[C@H]2C[C@H]1C2(C)C</smiles><smiles>C=C1C(=O)C[C@@H]2C3[C@@H]1CC[C@@H]32</smiles>

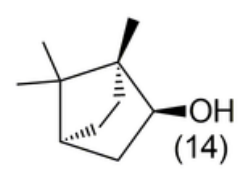<smiles>C[C@@H]1C(=O)C[C@H]2C[C@@H]1C2(C)C</smiles><smiles>C=C1CC[C@H](C(=C)C)C[C@@H]1O</smiles><smiles>CC(C)=CCC/C=C\CO</smiles>

(21)
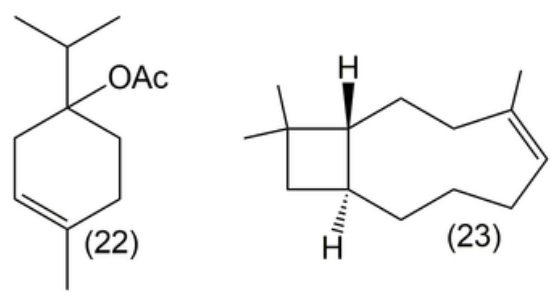<smiles>CC1=CCC(C(C)(C)O)CC1</smiles><smiles>C=C(C)[C@H]1CC[C@@H](C)C(=O)C1</smiles><smiles>C=C(C)[C@H]1CC[C@@H](C)C(=O)C1</smiles><smiles>C=C(C)[C@H]1CC[C@@H](C)C(O)C1</smiles>

Figure 5

Structures of the compounds identified in the leaf decomposition water at different periods (days) and in the aqueous extract of the leaves of the litter of E. urophylla.

\section{Supplementary Files}

This is a list of supplementary files associated with this preprint. Click to download.

- SupplementaryMaterialRitiellyMGGuerino.docx

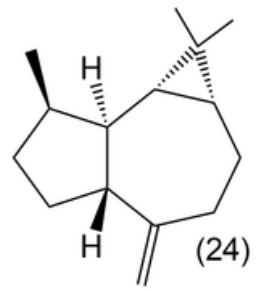



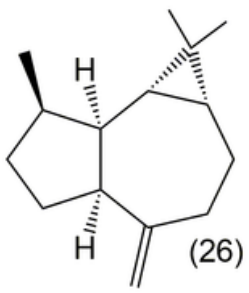

